\title{
Construction of Training Mechanism for Young Teachers' Practical Teaching Ability in Colleges and Universities
}

\author{
Zhiwei Sun \\ Department of Information Science and Technology,Tianjin University of Finance and Economics,Zhujiang \\ Road,Hexi District,Tianjin 300222,China \\ Sunzhiwei_0@163.com
}

Keywords: colleges and universities; Young teachers; Practical teaching ability; Cultivation mechanism

\begin{abstract}
The study starts from the college young teachers teaching ability and presents situation of deeply comprehensively analysis from the influence factors of the college young teachers practical teaching abilities. It puts forward to change the traditional teaching concept, strengthen self management and improve the system of job training, make close the school enterprise cooperation, the establishment of scientific practice teaching ability evaluation system, increase capital investment etc. The college young teachers teaching practice ability cultivation mechanism construction ideas, with a view to the college young teachers practical teaching abilities will help enhance.
\end{abstract}

\section{Introduction}

Be advised that papers in a technically unsuitable form will be returned for retyping. After returned the manuscript must be appropriately modified. Practice teaching is an important way to cultivate students' basic skills and practical ability, it can improve teaching quality. It is of great significance that we can improve the teaching ability of professional young teachers to improve the teaching level of professional theory and Practice. In recent years, in view of the present actual situation of young teachers in college, the exploration and practice on the cultivation of young teachers' teaching ability have been carried out, and a certain effect is obtained though building of “ three platforms "(i.e., experiment teaching platform, university-enterprise cooperation platform and academic exchange platform), implementating of "three plans"(i.e., young teachers cultivation plan, young teacher training plans and youth key teachers cultivating plans),and developing of "three activities"(i.e., teching competition and observation activites, teaching research and social practice activities)

However, most young teachers are graduates who have just graduated from universities, they all have higher education background and better professional basic knowledge, but most of them lack practical teaching experience. The training mechanism of colleges and universities is not perfect, and the evaluation and assessment system is unscientific, which affects the ability of young teachers to improve their practical teaching ability. In foreign countries, "teacher research has formed a specialized field". It has many advantages which strengthen the training of teaching ability of young teachers in practice, for example, it is conducive to the long-term development of young teachers and improve teachers' construction in competitiveness; it is beneficial to the local colleges and universities to improve the quality and level of education and it is conducive to social output highquality talents etc.. Therefore, it is very necessary and urgent to study the young teachers' practical teaching ability.

\section{Analysis of the current situation of young college teachers' practical teaching ability}

\subsection{It has initially established a practical teaching ability training system.}

In recent years, it has gradually been paid attention to the practice teaching of young teachers in 
colleges and universities. The Local governments have introduced relevant policies, and achieved good results. Some universities have initially established the training system of young teachers' practical teaching ability, so as to standardize the implementation process of practice teaching.

\subsection{It is a rich and varied form of practice teaching}

Colleges and universities combine their own actual situation and the characteristics of the region to carry out a variety of practical teaching activities. For example, in class practice teaching, teaching through social practice, etc. In the classroom teaching practice, students can take to analyze a problem free discussion and other forms of typical cases; social practice teaching can take the form of enterprise practice and social investigation. These various forms of practice teaching have made the local college young teachers practical teaching ability have been very good exercise and promotion, but also improve the enthusiasm of student participation.

\subsection{It has established a relatively perfect practice teaching base.}

In order to help young teachers to improve their practical teaching ability, colleges and universities have gradually established a relatively perfect training base for practical teaching. It provides a good school training environment for young teachers. It improves the quality of college education, through the establishment of a more perfect practice teaching base, can effectively improve the teacher's practical teaching ability.

\subsection{It pays attention to theoretical knowledge and neglects the cultivation of practical teaching ability.}

The purpose of teaching is to input applied talents for the society, so as to adapt to the fierce social competition environment. With the continuous expansion of local undergraduate colleges and universities, the introduction of young teachers has become an important measure for the expansion of faculty in major colleges and Universities. However, because a lot of young teachers are graduates of colleges and universities, they lack experience in the teaching process, they only stay in the theoretical level of teaching, practice teaching is not very seriously, resulting in the students' practice ability is relatively weak, unable to provide students with social practice and skills training opportunities. Therefore, the formation of a large number of talent output in colleges and universities, but the lack of talent enterprises embarrassing situation.

\section{Analysis of influencing factors of young college teachers' practical teaching ability.}

\subsection{The Willingness of young teachers is not strong to promote practical teaching ability.}

Due to some policies, young teachers in Colleges and universities pay more attention to their own educational background, promotion of professional title, and their economic income and social status, but ignore their own practical teaching ability. The young teachers themselves do not have much awareness to enhance practical teaching ability, the most important reason is that young teachers do not have the corresponding incentives to improve their enthusiasm. At present, colleges and universities have not established a sound evaluation system of practical teaching ability, and failed to combine with the title assessment of young teachers. The young teachers should spend more time and energy in practice teaching, but the reward is the same as that of theory teaching. Many young teachers are more inclined to choose theoretical teaching rather than practical course.

\subsection{The young teachers' knowledge structure is single and not updated in time.}

The practical teaching ability of young teachers is also influenced by their own knowledge system. Therefore, the knowledge system must be diversified, which not only requires young teachers to have a wealth of subject knowledge, but also should have rich practical work experience and experience, skilled teaching skills and other subject knowledge. Therefore, it is necessary for young teachers to constantly update their knowledge, actively practice exercise, and constantly improve their knowledge structure. However, in view of the current situation, most young teachers have a deep knowledge base, but most of them do not have practical work experience to process 
some of the sudden situation appears inexperienced. In the face of increasingly changeable social environment, young teachers do not have enough practical experience and skilled teaching methods, it can not meet the needs of the community, and affect the quality and level of local undergraduate colleges and universities ultimately.

\subsection{The training mechanism of practical teaching ability is not perfect.}

It has a direct impact on the education level and practical teaching ability of young teachers, which the perfection of training mechanism in Colleges and universities. At present, colleges and universities do not pay enough attention to the training of young teachers' practical teaching ability, even if the corresponding training mechanism has been formulated, however, the main points and key points of training can not be grasped, which often play a counterproductive role. The training mechanism is not perfect in two aspects: first, the content of training. The establishment of training mechanism in Colleges and universities is mainly for the purpose of improving the overall quality and ability of young teachers, young teachers can quickly adapt to college life and work, as soon as possible to understand and master the teaching methods and skills, they can quickly bring their own knowledge and practice experience into practice teaching ability in the teaching activities. However, the training mechanism in universities is obsolete and the training is lack of pertinence. Young teachers can not get what they need from the training mechanism, and the training mechanism achieves poor results. Secondly, the training way, the university training is still mainly in the form of teaching, mainly rely on class to pass theoretical knowledge to young teachers, lack of combination with practice. The young teachers are not impressed by these contents, and they are not impressed. The training methods are single, lack of flexibility and diversity, it can not improve the enthusiasm of young teachers, which led to the purpose of training is far from the actual situation.

\subsection{The evaluation mechanism of practical teaching ability is not reasonable.}

At present, most colleges and universities have established the relevant evaluation of the teacher. It is mainly to find out the shortcomings and shortcomings of young teachers in teaching, which is used to promote teachers to constantly improve their classroom teaching. However, many colleges and universities evaluation and assessment system positioning is not clear or wrong, leading to the results of evaluation and assessment is not good. The results are as follows: many universities pay more attention to scientific research projects than practice teaching; they only pay attention to the quantity of teachers published papers and the number of classes, but ignore the quality of teaching and the quality of academic papers. So many young teachers put most of their efforts on the number of papers published and the number of classroom teaching, no more time and effort to improve the ability of practical teaching. In the long run, the practical teaching ability of young teachers is weak, which affects the level of practice teaching in Local Universities.

\subsection{Colleges and universities are lack of good practice teaching environment.}

The construction of practice teaching environment influences young teachers' practical teaching ability to a certain extent. Good practice teaching environment can infect and lead young teachers consciously strengthen their practical teaching ability, instead, no practical teaching environment, teachers will have more inertia, don't say to improve their practice teaching ability. Many times, young teachers want to find some information or do some experiments, it can not meet the requirements. In addition, the management system of young teachers in Colleges and universities is unreasonable, which does not reflect democratization and legalization, and the demands of young teachers are often unable to solve. Furthermore, some local universities do not attach importance to young teachers who have just entered the school, which to some extent bring some influence to the young teachers' psychology. In this kind of campus environment, it is difficult for young teachers to devote themselves to teaching, not to mention improving the practical teaching ability.

\subsection{The government and universities have invested insufficient funds for practical teaching.}

The government, colleges and universities do not have enough investment in young teachers' practical teaching ability. According to the statistics on the implementation of the National 
Education Fund, It can be seen that the state of the education funding increases, but the university funding in the lower, higher education funds decreased to some extent reduce the enthusiasm of local colleges and universities on the cultivation of young teachers. From the perspective of local undergraduate colleges and universities, local colleges and universities in the new profession declaration, scientific research projects, teaching reform and other aspects of the investment is higher, the young teachers practical teaching ability to raise funds for investment is insufficient. With the continuous deepening of reform and opening up, the rapid development of the national economy, ranked second in the world, there is an urgent need of applied talents, which requires colleges and universities must adapt to the current situation, a positive declaration of new professional training, various types of talents. However, once the new profession is successfully declared, in order to ensure the normal development of the new profession, a lot of money will be tilted to the new profession, resulting in reduced funds in other areas. In the research project, many scientific research will carefully prepared in the earlier period, the University also provides a lot of money for young teachers, but at a later stage, how the young teachers in practice, the number of harvest but can make nothing of it lack of supervision of the process. In addition, local undergraduate colleges and universities have been expanding, it spent more money on infrastructure construction, the teaching ability of young teachers training practice of the investment will be relatively small, lack of school resources, it further hindered the young teachers' practical teaching ability.

\section{Construction of training mechanism for young teachers' practical teaching ability in Universities.}

\subsection{We should change the traditional teaching concept and strengthen the young teachers' understanding of the cultivation of practical teaching ability.}

At present, the society is more in urgent need of compound applied talents, more and more attention to students' practical ability. This poses a great challenge to young teachers. At present, the young teachers are deeply influenced by traditional teaching ideas, their training of students just teaching theoretical knowledge, combined with the actual situation is not very good, there is no practical teaching activities rich and diverse, it is difficult to cultivate practical talents for the requirements of the times, therefore, we need to change the traditional concept of young teachers. Developed countries do better in this respect. For example, in the process of young teacher training in the United States, special emphasis is put on the concept of teachers' practical teaching, and that education is an important way to change the future, focusing on the cultivation of students' adaptability to society. By changing the concept of young teachers, they should pay more attention to the teaching of students' practical experience and skills in the actual teaching process. The government and local universities can learn some foreign good practices, strengthen the cultivation of advanced teaching idea of young teachers, and raise the level of awareness of young teachers, so that they recognize the cultivation of students' practical ability of teachers have a significant impact, we should also be aware of the teaching level of teachers directly affect the school's reputation and future development. The voluntary acceptance of advanced teaching ideas. Therefore, the internal local universities can organize such as lectures, speech contests and other forms of activities, and actively promote the advanced teaching idea, strengthen the training of young teachers to practice teaching ability, and actively improve their own practical teaching ability.

\subsection{We should strengthen the self management of young teachers, and constantly improve the knowledge structure.}

We can strengthen the self management of teachers from three aspects. First of all, we should improve the awareness of self development of young teachers, and establish the concept of lifelong learning. Young teachers should develop their ability of independent study and development, strengthen their study of theoretical knowledge, enrich and innovate constantly so as to keep pace with the times. Only by establishing the advanced concept of lifelong learning, constantly 
improving their own knowledge structure, mastering the forefront of knowledge and skills, we can impart useful practical skills to students, meet the requirements of society for talents. Secondly, we should enrich our own practical experience, strengthen the practice teaching skills training. Young teachers can actively participate in teaching activities of various kinds, such as participating in teaching competitions through this lecture scene in the form of games, and actively learn from other outstanding young teachers teaching strengths, and improve the teaching ability of practice continuously. Finally, young teachers should develop good habit of teaching reflection. Teaching reflection is very important, young teachers through the lesson plans formulated by reflection, reflection and summary of the work and the middle class final work summary, find their own problems and shortcomings, try to figure out which accords with the practice of new teaching methods and is suitable for the students, and develop a good habit of introspection.

\subsection{We should improve the post training mechanism and focus on the cultivation of young teachers' practical teaching ability.}

The job training includes two aspects: pre job training and on-the-job training. On the one hand, pre job training mainly aims at training young teachers' related theoretical knowledge and teaching skills, which is the main way to improve their practical teaching ability. Because young teachers lack practical teaching ideas before work, our pre job training can help young teachers set up the concept of practical education and teaching, so that young teachers can carry out practical teaching in the course of class. Therefore, the university must improve the young teachers' pre employment training work seriously, establish a special pre service training institutions actively, set up the corresponding training department, and set up training system, the pre service training work more standardized, diversified training content. Colleges and universities can invite teachers and experts from home and abroad to carry out special lectures, which can train teachers to teach lessons, compete and promote each other. On the other hand, the main purpose of in-service training is to constantly strengthen their own practical teaching ability, and enhance their own quality in the actual work constantly. The young teachers' in-service training is essential, we generally take out short-term learning, mentoring, further education and other diverse forms of training, which can strengthen the cultivation of teaching ability of young teachers in practice.

\subsection{We should establish a scientific evaluation system, play its guiding role.}

The mechanism of evaluation of practice teaching ability evaluation is conducive to improve the teaching ability of young teachers to improve the practice, it can fully arouse the enthusiasm of young teachers, to join in the teaching practice to improve the teaching quality. The university must evaluate the teaching of young teachers, which includes student evaluation, teacher evaluation, leadership assessment etc., we assessed the title of young teachers still pay attention to "Virtue", "energy", " industrious ", "performance" of the four aspects, however, young teachers' teaching practice ability evaluation not strict enough. Therefore, we should improve the evaluation system of young teachers, it must be study practice teaching ability is also included, strict requirements, especially the construction of local application of high level university, we should do this work as soon as possible. In this way, can gradually form the theory of "teaching workload, practice teaching workload, scientific research and teaching quality as the basis, comprehensive evaluation system and combined with the technical evaluation, wages and welfare and so on, we can be appropriate to give preferential treatment to the practice of teaching ability of young teachers, improve the enthusiasm and the initiative of young teachers constantly.

\subsection{We should contact the school and enterprise, and build the platform for young teachers to improve their practical teaching ability.}

It is not enough to improve the practical teaching ability of young teachers in Colleges and universities only through the training on campus, and it needs to rely on the power of society. The enterprise provides a good social training for the promotion of young teachers' practical teaching ability platform. Only when young teachers participate in the actual production and operation of enterprises, can they learn and master the most advanced knowledge and related ability, which helps 
to strengthen their practical teaching ability fundamentally. In the exchanges and cooperation between universities and enterprises, the government should give full play to its functions, develop and implement relevant laws and regulations of the school enterprise cooperation actively, we can set up a special fund for cooperation between school and enterprise, to help the young teachers in Colleges and universities in the training of outstanding enterprises from the capital, but also setting reward or appropriate relief on taxes and other measures from the policy. Universities should seek to cooperate and communicate with the enterprise actively, and build a good platform for the school external training of young teachers, young teachers should support to business practice and training, so that the teachers fully abreast of the latest technology of current enterprise and changes in the demand for talent. Through the joint efforts of the government and local undergraduate colleges and universities, school and enterprise cooperation will have a good impact on young teachers' practical teaching ability training.

\subsection{We need to increase funding and provide long-term funding guarantees.}

Colleges and universities are developing rapidly, but the school resources are seriously lacking. The government should realize that the lack of funds will lead to the decline of the school running level, and lead to the reduction of the talents sent by universities directly. Therefore, the government should give full play to its guiding role and increase the capital input of colleges and universities. At present, the government of the money is mainly used for the school infrastructure construction, wage subsidies, and young teachers training funds is less, in this regard, the government should put the young teachers training costs into government funding, focusing on increasing the teaching practice ability training funds. At the same time, we should supervise and manage the funds so as to ensure the smooth implementation of the funds strictly.

\section{Conclusion}

The young teachers are the main participants in the construction and development of local undergraduate colleges and universities. The promotion of their practical teaching ability is the key to the cultivation of Application-oriented Talents The government, universities and young teachers should pay attention to it, the government should strengthen the guidance of local undergraduate colleges and universities, we should provide protection for the cultivation of young teachers in Colleges and universities to enhance practice teaching ability through the economic, political and legal means; In order to improve the enthusiasm and creativity of young teachers' practical teaching ability, colleges and universities should improve the training and assessment mechanism of young teachers' practical teaching ability.

\section{Research project}

Undergraduate teaching reform project of Tianjin University of Finance and Economics in 2017: Research on the cultivation of practical teaching ability of young teachers in our school.

\section{References}

[1] Xu Lihua, Wu Wensheng. Teacher's professional growth organization: Teacher Collaboration

Learning community [J]. Teacher education research, 2005 (5): 44 - 46.

[2] Zhu Haixue, Song Zhen. The construction of teaching ability training system for young teachers in local universities [J]. Time education, 2016 (5): 17 - 18.

[3 Guo Song. Bottleneck and Countermeasures for improving the practical teaching ability of young teachers [J]. Education and teaching forum, 2016 (5): 273 - 274.

[4] Zou Li. Research on ways to improve young teachers' practical teaching ability [J]. Managers, 2014 (32): 244. 
[5] Lin Jifu, Xiong Deng. On the construction of young college teachers under the guidance of Scientific Outlook on Development [J]. Research on teachers in Chinese universities and colleges, 2014 (1): 29 - 34.

[6] Zhang Leyong, Zhang Qingrong, Ma Gang, et al. Construction and practice of young teachers' teaching ability training system [J]. Petroleum education, 2015 (1): 91 - 93. 